\title{
The Cultivation of Melon on Swamp Floating Bed in Central Kalimantan, Indonesia
}

\section{HASTIN ERNAWATI NUR CHUSNUL CHOTIMAH ${ }^{1^{*}}$, GUSTI IRYA ICHRIANI ${ }^{1}$, WAHYU WIDYAWATI ${ }^{1}$, MOCH ANWAR ${ }^{1}$, EXWAN PRASETYO ${ }^{1}$, AND ARDIANOR ${ }^{2}$}

\author{
${ }^{1}$ Program Study of Agrotechnology, Department of Agronomy, Faculty of Agriculture, University of \\ Palangka Raya. Jl. Yos. Sudarso, Palangka Raya (73111), Central Kalimantan, Indonesia \\ ${ }^{2}$ Department of Aquatic Resources Management, Faculty of Agriculture, University of Palangka Raya. Jl. \\ Yos. Sudarso, Palangka Raya (73111), Central Kalimantan, Indonesia
}

\begin{abstract}
Cultivating of melon particularly in Central Kalimantan has been widely undertaken by farmers, however, the yields have not been able to meet the melon needs of Central Kalimantan's community. One of the breakthroughs in overcoming the problem is by growing melons on swamp floating beds, known in Kalimantan as ambul technology. Ambul is growing media from decomposed floating aquatic plants, constructed with bamboo or wooden as a frame, that is let floating on waters. The ambul based on the consideration that the community lacks access to land for most of the year, which reduces opportunities for growing crops. The research design used was Split Plot Design with three kinds of aquatic plants as the main factor namely Eichornia crassipes, Salvinia molesta, Eleocharis palustris, and two melon varieties as subplot factors specifically Action 434 and Amanta. The results showed that the Amanta variety grown on $S$. molesta media produced the highest value of crop length on 1, 2, 3 weeks after planting (WAP). S. molesta was the best planting media for enhancing flowering by 11.43 days after planting (DAP) and weight of fruit was $3.18 \mathrm{~kg}$ per plant. The variety of Amanta also had the highest value of root dry weight of $1.33 \mathrm{~g}$ per plant and fruit weight of $2.08 \mathrm{~kg}$ per plant.
\end{abstract}

Keywords: Decomposed-Aquatic Plants; Floating Bed; Melon Varieties; Swamp

\section{INTRODUCTION}

Melon is one of the economically important fruit and is a source of vitamins and minerals to improve nutrition. Melon is in high demand in tropical markets especially in urban markets (Ibironke \& Oyeleke, 2014). Melon production contributed only about 0.76 percent of the national fruit production (Direktorat Jenderal Hortikultura, 2015). According to agricultural indicators, although both of the area of harvest and production of melon increased from the previous year, the production only reached 121,949 tons with $8,632 \mathrm{Ha}$ harvested areas in Indonesia (BPS, 2020). In Central Kalimantan, the harvested area is only about 66 ha in 2019, melon production reached 435 tons in 2018 (BPS of Kalimantan Tengah, 2020). The low production of melon is affected by some factors. Among the production factors, nutrients and water are the most factors that limiting to higher melon yields (Monteiro et al., 2014).

Swampland area in Indonesia reaches 33.4 million ha (Haryono et al., 2013) including peat swampland of around 14.9 million ha (Ritung et al., 2011). In Central Kalimantan, peat-swamp forests dominate swampland characterized by the poor nutritional condition. Of the entire existing swampland, about 5,720 ha of these are considered to have the potential for agriculture

Correspondence: Hastin Ernawati Nur Chusnul Chotimah. Program Study of Agrotechnology, Department of Agronomy, Faculty of Agriculture, University of Palangka Raya. Jl. Yos. Sudarso Palangka Raya (73111), Central Kalimantan, Indonesia. Email: hastinwindarto@agr.upr.ac.id. 
production (Ritung et al., 2011). The Arut Village floodplain is derived from the overflow of Kahayan River, a longest main river in Central Kalimantan. As a result, the land becomes unproductive for a long period of a year. It is indeed too difficult for the community to continue the agricultural practice. Besides, the land covered by almost aquatic plants and is not possible for planting activities. Floating agriculture by utilizing aquatic plants is possibly introduced to overcome such the problem. Hence, one of the solutions is the cultivation of melon on a swamp floating bed known as ambul.

Ambul is formerly adopted from the traditional practice of cultivation in the Bangkau Lake, South Kalimantan Indonesia. It is a hydroponics system like or soil-less culture. As planting media, the ambul is in a manner constructed from decomposed aquatic plants and let float on the surface of waters in the swampy area (Ardianor et al., 2007; Pantanella et al., 2011). The ambul concept is similar to Baira (Irfanullah et al., 2008 ; Forneck et al., 2015), floating agriculture (Assaduzzaman, 2004), Floating Island planting system (Schuck, 2005), floated-cultivation (Bernas et al., 2012), floating rafts technology (Marlina \& Syafrullah, 2014), or floating treatment wetlands (Headley \& Tanner, 2008 ; Bulut, 2011).

In Central Kalimantan, the ambul is based on the consideration that the local community has lacked access to land due to inundated for most of the year, which reduces opportunities for growing crops. The ecological benefit to the aquatic ecosystem is also important recognized so far since this simple technology is able to reduce the expansion of covering densely floating aquatic plants on the swamp surface. Other advantages of ambul are not require watering due to water diffuses from the bottom, not need fertilizers so that organically, and a wise system in maintaining the balance of the

swamp. The vegetable planting can be undertaken several times in one flood season, so it can increase farmer's income. Floating agriculture is very effective, especially to minimize crop damage when floods occur. Production of this low technology has the potential to increase productivity per unit of land without chemical fertilization treatment. Residue from floating agriculture after harvest is an organic material that is useful for the next planting process. Cost and profit estimates show that there is a positive relationship between net return (NR) and bed size of a floating garden. For bed size $\left(4.3 \times 1.2 \times 0.9 \mathrm{~m}^{3}\right)$, the NR value is USD 111.55, and BCR is USD 3.67 (Forneck et al., 2015). Further, Forneck et al. (2015) reported that floating agriculture creates employment opportunities thereby reducing labor migration to urban areas since it provides jobs in rural areas. Floating agriculture is also beneficial to landless farmers due to flooding as it ensures better food security (Chowdhury \& Moore, 2017).

The objectives of this study were (1) to evaluate the interaction between decomposed floating aquatic plants as planting media and melon varieties, (2) to evaluate the effect of aquatic plants and (3) the effect of varieties on melon growth and yield cultivated on ambul swamp floating bed.

\section{MATERIALS AND METHODS}

The research was conducted in Arut Bawah floodplain wetland in Palangkaraya, Central Kalimantan located at an altitude of 20-25 m above sea level from Januari until May 2015. The location of Arut is $2.20^{\circ} \mathrm{S}, 113.92^{\circ} \mathrm{E}$. An artificial floating bed named ambul whose size was $9 \times 10 \mathrm{~m}^{2}$. The ambul was constructed using bamboo tied resembling raft so it could float. The floating media consisted various aquatic plants i.e E.crassipes, S.molesta and 
E.palustris. The piling up of aquatic plants on ambul as a planting media was done in reverse, shoot section below while the roots were above. The root sections then were chopped manually by chopper. The total expanse area of E.crassipes, S.molesta and E.palustris required to fill $9 \times 10 \mathrm{~m}^{2}$ ambul were $960 \mathrm{~m}^{2}, 2160 \mathrm{~m}^{2}$ and $1850 \mathrm{~m}^{2}$, respectively. The ambul media thickness was $50 \mathrm{~cm}$. Before planting, the media was incubated for a month to form compost. Planting was done after the 10-days-old seedlings in nurseries with a spacing of $50 \times 60$ $\mathrm{cm}$. Basic fertilizers in the early planting were $15 \mathrm{t} / \mathrm{ha}$ of chicken manure, meanwhile, at 1 to 7 weeks after planting (WAP) was given 200 $\mathrm{kg} / \mathrm{ha}$ of NPK fertilizer and $2 \mathrm{t} / \mathrm{ha}$ of dolomite. Harvesting was executed at 65 days after planting (DAP) with fruit skin color turned yellowish. The research was conducted to follow Split Plot Design with three aquatic plants as the main factor and varieties as subplot factors. The aquatic plants included $E$. crassipes, S. molesta and E. palustris. The subplot factors were two varieties of melon, namely Action 434 and Amanta. Each combination of treatments classified as 4 groups in order to obtain 12 main plots and 24 subplots. Variables observed were plant length, flowering time, root dry weight, and fruit weight. Data

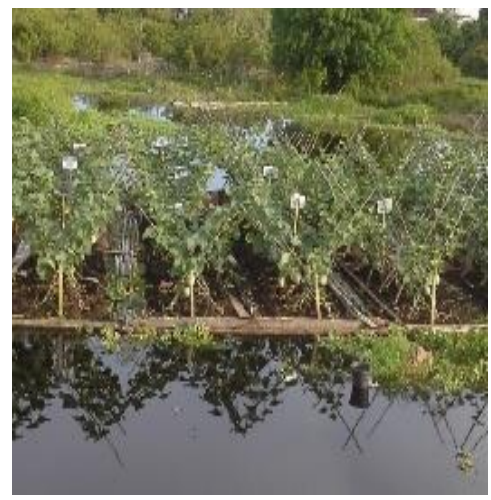

Figure 1. Melon on swamp floating bed

\section{Length of Plants}

There was an interaction between planting media and variety used on plant length at 1, 2, Journal of Wetlands Environmental Management Vol. 8, No 2 (2020) 129-138 http://dx.doi.org/10.20527/jwem.v8i2.244 was performed by analysis of variance in the level of $5 \%$. If there was an effect on the treatment, it was then continued by Duncan Multiple Range Test (DMRT) at 5\% error level.

\section{RESULTS}

\section{Performance of Ambul with Melon}

Visualization of melon cultivated on floating bed is presented in Figure 1. The exact location was under the Sukarno Bridge that connects the city of Palangka Raya with Bukit Rawi, Barito Selatan, and Gunung Mas. The floating bed was mobile like an island in the middle of the waters. The application of S. molesta as media of ambul based on the consideration that $S$. molesta is one of the many plants in the floodplain and its existence disrupts aquatic ecosystems as well as E. crassipes and $E$. palustris. The other aquatic plants were grasses, water spinach and limnocharis or sawah-lettuce which were potential to be used as growing media on floating beds. The depth reached approximately three meters located on the edge of the Kahayan river. The most common pest found in the cultivating of the melon float system was the rat.

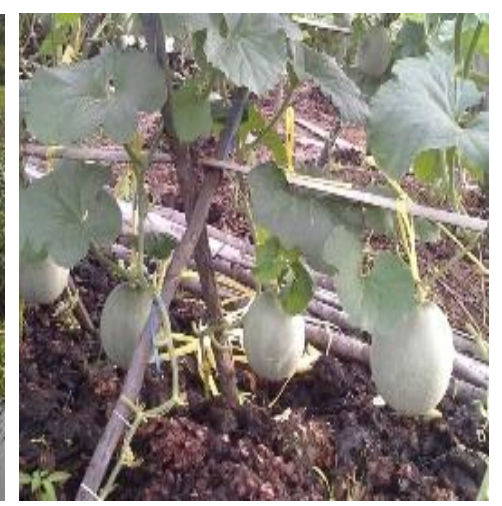

and 3 WAP $(\mathrm{p}<0.05)$ but not so with those at 4 WAP ( $>0.05)$. At 4 WAP, plant length of melon only was affected by melon varieties $(p<0.05)$. The Amanta variety produced the $(p<0.05)$. The Amanta variety produced the 
highest plant length $(188.43 \mathrm{~cm})$ and had and $114.35 \mathrm{~cm}$, respectively. The use of significantly different from the length of the S.molesta as a planting media in the form of variety of Action 434. Application of S. molesta and Amanta variety produced the longest plant at age 1, 2, and 3 WAP by $14.6 \mathrm{~cm}, 43.13 \mathrm{~cm}$ compost also produced the highest melon plant length of both Amanta and Action 434 varieties (Table 1).

Table 1. Plant length $(\mathrm{cm})$ of two varieties of melon at 1, 2, 3 and 4 WAP on ambul on various planting media

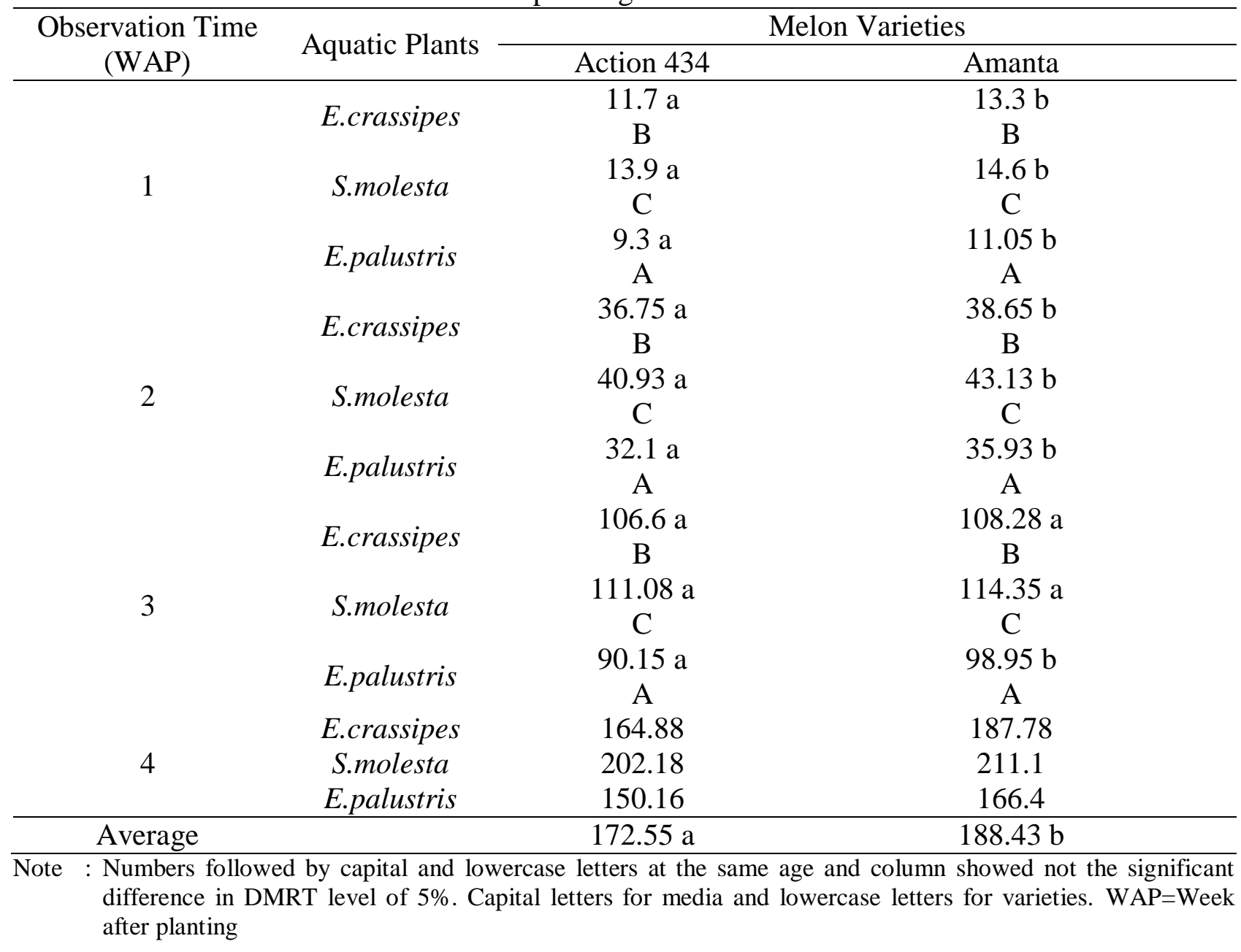

\section{Flowering Time}

Production of melon depends on a series of steps in reproductive development, flowering, fruit set and growth, maturation and ripening. In flowering time, there was no interaction between media used and melon variety ( $\mathrm{p}>0.05)$. The only the aquatic plants as media exhibited flowering time of melon on ambul $(\mathrm{p}<0.05)$. The utilization of $S$. molesta as planting media accelerated the time of flowering on both Action 434 and Amanta (11.43 DAP) and significantly different from other planting media. The melon cultivated on ambul swamp floating bed would be flowering at 11.43 days on S. molesta, 12.29 days on E. crassipes and 12.49 days on E. palustris, respectively (Table 2). 
Table 2. Flowering time, root dry weight, and fruit weight of two varieties of melon on ambul on various planting media.

\begin{tabular}{|c|c|c|c|}
\hline \multirow{2}{*}{ Aquatic Plants } & \multicolumn{2}{|c|}{ Melon Varieties } & \multirow{2}{*}{ Average } \\
\hline & Action 434 & Amanta & \\
\hline \multicolumn{4}{|c|}{ Flowering Time (day after panting) } \\
\hline E.crassipes & 12.33 & 12.25 & $12.9 \mathrm{~B}$ \\
\hline S.molesta & 11.93 & 10.93 & $11.43 \mathrm{~A}$ \\
\hline E.palustris & 12.58 & 12.40 & $12.49 \mathrm{~B}$ \\
\hline \multicolumn{4}{|c|}{ Root Dry Weight（g) } \\
\hline E.crassipes & 1.14 & 1.36 & $1.25 \mathrm{~B}$ \\
\hline S.molesta & 1.40 & 1.72 & $1.56 \mathrm{C}$ \\
\hline E.palustris & 0.72 & 0.92 & $0.82 \mathrm{~A}$ \\
\hline Average & $1.09 \mathrm{a}$ & $1.33 \mathrm{~b}$ & \\
\hline \multicolumn{4}{|c|}{ Fruit Weight $(\mathrm{kg})$} \\
\hline E.crassipes & 2.35 & 2.83 & $2.59 \mathrm{~B}$ \\
\hline S.molesta & 2.98 & 3.38 & $3.18 \mathrm{C}$ \\
\hline E.palustris & 1.75 & 2.08 & $1.92 \mathrm{~A}$ \\
\hline
\end{tabular}

Note : Numbers followed by same letters at the same column and parameter showed not the significant difference in DMRT level of $5 \%$.

\section{Root Dry Weight}

In this experiment, the plant roots were not in contact with the bottom sediments or soil. Their access to nutrients depends on the nutrients contained within the floating bed, much like a hydroponic cultivation system. The analysis of variance results showed that there was no interaction between planting media and melon varieties $(\mathrm{P}>0.05)$. The single effect occurred either in the planting media or varieties treatment $(\mathrm{P}<0.05)$. The root dry weight of Amanta variety was higher than those of Action variety $(1.33 \mathrm{~g})$. The administration of $S$. molesta as planting media produced the highest root dry weight $(1.56 \mathrm{~g})$ compared to those treated with E.crassipes dan E.palustris (Table 2).

\section{Fruit Weight}

The provision of various aquatic plants as planting media had a significant effect on fruit weight $(\mathrm{P}<0.05)$, but there was no impact of variety on fruit weight $(\mathrm{p}>0.05)$. The highest fruit weight was generated by melon treated with $S$. molesta as planting media $(3.18 \mathrm{~kg}$ per Journal of Wetlands Environmental Management plant) and there was significantly different from others (Table 2).

\section{DISCUSSION}

To date, melon has never been cultivated floatingly in Central Kalimantan. The cultivation of ambul is only limited to several commodities. Ardianor et al. (2007) introduced an ambul to the community to cultivate cash crops in Sabuah Lake, Central Kalimantan. The same cultivation also was undertaken by Chotimah et al. (2014) in Arut Village by growing various vegetables such as cucumber, bitter gourd, squashlike vegetables/sponge luffa, eggplant, tomato, and okra. The growth and yield obtained by residents of the various vegetables were very satisfactory although the yields were only used to meet their daily needs of vegetables in the household. The cucumber yields reached $4 \mathrm{~kg} /$ plant, eggplant $3 \mathrm{~kg} / \mathrm{plant}$, tomato $1.5 \mathrm{~kg} /$ plant, and squashlike vegetable 4 $\mathrm{kg} /$ plant, respectively. Nevertheless, the farming analysis of some ambul's vegetables has not provided an economic advantage due to the cost to assemble of the ambul. In other words, the cultivated plant on ambul must have a high 
economic value such as chilies and melons. (Pantanella et al., 2011) declared that productivity of cabbage (Brassica campestris L) in composted manure rafts and lettuce (Lactuca sativa L) in nutrient-rich ponds resulted in the same productivity in a high-input agricultural field.

On floating melon, plants grow and produce well. The variety of Amanta attained $188.43 \mathrm{~cm}$ plant height, whilst the Action 434 reached $172.55 \mathrm{~cm}$ at 4 WAP (Table 1). Simanungkalit et al., (2013) reported that the treatment with 45 g NPK fertilizer produced the longest shoot $(200.24 \mathrm{~cm})$ at 5 WAP on Action 434 on nonfloating melon. Risyad \& Ainun, 2015 reported that the height of non floating melon reached $168.66 \mathrm{~cm}$ with treatment of planting media and Agroboost biofertilizer and $416.83 \mathrm{~cm}$ with bokashi and KNO3 at 30 days after planting. The plant height in the ambul reached 202.18 $\mathrm{cm}$ and $211.1 \mathrm{~cm}$ in the varieties of Action 434 and Amanta with ambul media of S.molesta, respectively (Table 1). The use of organic materials as a medium of non-floating melon cultivation has been done (Risyad \& Ainun, 2015; Mazuela \& Urrestarazu, 2009; Bariyyah et al., 2015; Amiroh, 2014) but not so with the use of organic material from decomposedaquatic plants on floating melon.

The application of S.molesta compost on melon floating bed is suitable media due to the increasing all of the parameter observed whereas in some areas S.molesta cause the problems by its excessive growth (Chomchalow, 2011; European and Mediterranean Plant Protection Organization, 2017 ; Hussner et al., 2017). In the size frame 9 $\mathrm{x} 10 \mathrm{~m}^{2}$ of this ambul needs $2160 \mathrm{~m}^{2}$ area of S.molesta with the result that this practice provides a biological control for this invasive aquatic weeds effectively. The S.molesta compost is suitable media compared with E.crassipes and E.palustris due to both nutrients and hormones content. This is because
S.molesta has a softer morphology than E.crassipes and E.palustris so it is suspected that the protein and mineral content in S.molesta is more than that of E.crassipes and E.palustris and is easier to decompose well so that it is able to contribute elements nitrogen, phosphorus, and others. This phenomenon is in line with (Marlina \& Syafrullah, 2014) report. Further, the dry matter of $S$. molesta contained $135 \mathrm{~g} / \mathrm{kg}$ of lignin, $42 \mathrm{~g} / \mathrm{kg}$ ether extract, $130 \mathrm{~g} / \mathrm{kg}$ of ash and $132 \mathrm{~g} / \mathrm{kg}$ of crude protein (Leterme et al., 2010 in Koutika \& Rainey, 2015). The experiment of (Arthur et al., 2007) detected that S.molesta compost consisted of the macronutrients ( $\mathrm{N}, \mathrm{P}, \mathrm{K}, \mathrm{Na}, \mathrm{Ca}, \mathrm{Mg}, \mathrm{Fe}$ ) and plant hormones (IAA and cytokinins).

The switch to reproductive development is clearly controlled by endogenous and several environmental condition. There is recent evidence that flowering time is controlled by genes. These genes affect the hybrid vigor and thus are likely to impact on yield. In all seed crops, the floral transition is a key developmental switch that determines the production of dry matter (Jung \& Müller, 2009). Melon cultivation utilized of $S$. Molesta as a media floatingly was able to shorten the flowering time of plants. The first time of Amanta variety flowering at 10.93 DAP meanwhile the Action variety flowering at 11.93 DAP (Table 2). The flowering time is faster than the findings (Syafi'i, 2005). Melons are grown with a drip irrigation hydroponic system with GA3 treatment. The flowers will appear for the first time in 18 DAP.

In correlation studies with melon, fruit weight has been reported to be positively correlated with plant length $(r=0.59)$ (Taha et al., 2003). The results of this study also tend to follow the pattern of these correlation. The application of S.molesta induced both plant length (Table 1) and heaviest fruit weight at $3.38 \mathrm{~kg}$ in the Amanta variety (Table 2). In nonfloating, fresh weight of melon gains 
approximately $1815 \mathrm{~g}$ per plant (Sari et al., 2012), 1244 g (Park \& Seo, 2012), 1.64 kg (Surtinah, 2017), $2.68 \mathrm{~kg}$ (Makful et al., 2013), $1792 \mathrm{~g}$ (Asao et al., 2013), $1.17 \mathrm{~kg}$ (Mustaqim et al., 2016), and $1.52 \mathrm{~kg}$ (Deus et al., 2014) in the field. The Action 434 reportedly reached only the weight of $1.59 \mathrm{~kg}$ (Deus et al., 2014). At various altitudes, the Apollo variety is the most suitable for the lowland and highlands with yields of $0.56 \mathrm{~kg}$ per plant (Afandi et al., 2013). The potential conventional soil cultivation melon weight of Action 434 and Amanta was $2.2 \mathrm{~kg}$ per plant and $3.5 \mathrm{~kg}$ per plant, respectively (Personal communication: PT. Tanindo Subur Prima and PT. East West Seed Indonesia). The fruit weight in the experiment achieved $2.98 \mathrm{~kg}$ per plant of Action 434 and $3.38 \mathrm{~kg}$ per plant of Amanta arranged one fruit per plant (Table 2).

Soilless culture in the form of a float tray system involves the use of media substrates the use of aquatic plant compost media provide advantages such as enabling root growth and improved germination rates (Wisdom et al., 2017). The root dry weight of $1.09 \mathrm{~g}$ of Action and $1.33 \mathrm{~g}$ of Amanta. The weighty root was pointed by impacted E.crassipes, S.molesta and E.palustris as a media of melon swamp foating bed $1.25 \mathrm{~g}, 1.56 \mathrm{~g}$, and $0.82 \mathrm{~g}$, respectively (Table 2). At the whole ecosystem scale, fine root biomass was negatively related to nutrient availability, however, Neatrour (2005) reported within floodplain ecosystem which is the greatest $\mathrm{NO}_{3}-\mathrm{N}$ and $\mathrm{NH}_{4}-\mathrm{N}$ variability and nutrient undistributed spatially, the correlation was weak. Soil nutrient availability may control fine root biomass at the ecosystem scale in the wetland ecosystems. Visually, the growth of melon roots penetrated in the shallow layer $(<20$ $\mathrm{cm}$ ) on the ambul. There seems to avoid contact with the surface of the swamp water. Sharma et al. (2017) argued that in melon irrigated crops, the distribution of root in the soil profile might not represent the effectiveness of root.
Furthermore, genotypic differences are very responsible for the melon ability to adjust root distributions pattern across soil depth.

\section{CONCLUSION}

There was no interaction between both melon variety used and decomposed floating aquatic plant types on ecotechnology ambul cultivation. The decomposed floating aquatic plants of S.molesta as a media is recommended to be applied as a soil replacement media for melon on swamp floating bed cultivation. The make use of melon varieties is a major factor that must be considered. Among the two varieties, Amanta is the variety supporting for swamp floating bed cultivation evidenced some plant growth and yield indicators observed.

\section{ACKNOWLEDGMENT}

We would like to thank to Directorate General of Higher Education, Ministry of Education, Indonesia for granting financial support and Mr. Sunyahdi for technical assistance.

\section{REFERENCES}

Afandi, M. A., Sulistyono, R., \& Herlina, N. 2013. Respon Pertumbuhan Dan Hasil Lima Varietas Melon ( Cucumis Melo L .) Pada Tiga Ketinggian Tempat. Jurnal Produksi Tanaman, 1(4), 342-352. http://protan.studentjournal.ub.ac.id/index.p hp/protan/article/viewFile/43/43.

Amiroh, A. 2014. Pengaplikasian Dosis Pupuk Bokashi dan KNO3 Terhadap Pertumbuhan dan Hasil Tanaman Melon (Cucumis melo L). Saintis, 6(2), 25-36.

Ardianor I, Buchar T, Handayani T, Wulandari L, Aunurafik, Liwat Y, Najamudin A, Gumiri S. 2007. Ambul : A traditional farming system on open water in 
Kalimantan. Proceeding of International Workshop on : Human Dimension of Tropical Peatland Under Global Environmental Changes. December 8-9. Bogor Indonesia

Arthur, G. D., Stirk, W. A., Novák, O., Hekera, P., \& van Staden, J. 2007. Occurrence of nutrients and plant hormones (cytokinins and IAA) in the water fern Salvinia molesta during growth and composting. Environmental and Experimental Botany, 61(2), 137-144. https://doi.org/10.1016/j.envexpbot.2007.05 .002

Asao, T., Asaduzzaman, M., Mondal, M. F., Tokura, M., Adachi, F., Ueno, M., Kawaguchi, M., Yano, S., \& Ban, T. 2013. Impact of reduced potassium nitrate concentrations in nutrient solution on the growth, yield and fruit quality of melon in hydroponics. Scientia Horticulturae, 164, 221-231.

https://doi.org/10.1016/j.scienta.2013.09.04 5

Assaduzzaman, M. 2004. Floating Agriculture in the flood-prone or submerged areas in Bangladesh (Soutern regions of Bangladesh). Bangladesh Resouce Centre for Indigenous Knowledge (BARCIK). Dhaka. Bangladesh.

Bariyyah, K., Suparjono, S., \& Usmadi, U. 2015. Pengaruh Kombinasi Komposisi Media Organik dan Konsentrasi Nutrisi terhadap Daya Hasil Tanaman Melon (Cucumis melo L.). Planta Tropika: Journal of Agro Science, 3(2), 67-72. https://doi.org/10.18196/pt.2015.041.67-72

Bernas, S. M., Pohan, A., Fitri, S. N. A., \& Kurniawan, E. 2012. Model Pertanian Terapung dari Bambu untuk Budidaya Kangkung Darat ( Ipomoea reptans Poir .) di Lahan Rawa. Jurnal Lahan Suboptimal, 1(2), 177-185.

Anonimous ${ }^{\mathrm{a}}$. 2020. Statistical Yearbook Of
Indonesia 2020. Biro Pusat Statistik Pusat https://www.bps.go.id/publication/2020/02/ 28/6e654dd717552e82fb3c2ffe/statistikindonesia--penyediaan-data-untukperencanaan-pembangunan.html

Anonimous ${ }^{b}$. 2020. Kalimantan Tengah Province In Figure. Biro Pusat Statistik Kalimantan Tengah.

Bulut, I. 2011. Floating islands of Turkey. Procedia - Social and Behavioral Sciences, 19 , 526-531. https://doi.org/10.1016/j.sbspro.2011.05.16 5

Chomchalow, N. 2011. Giant Salvinia - An Invasive Alien Aquatic Plant in Thailand. 15(2), 77-82.

Chotimah, H. E. N. C., Ichriani, G. I., \& Ardianor. 2014. Introduksi Teknologi Inovasi Ambul Untuk Budidaya Tanaman Sayuran Di Kalimantan Tengah. 13(1), 4-7.

Chowdhury, R. B., \& Moore, G. A. 2017. Floating agriculture: a potential cleaner production technique for climate change adaptation and sustainable community development in Bangladesh. Journal of Cleaner Production, 150, 371-389. https://doi.org/10.1016/j.jclepro.2015.10.06 0

Deus, A. De, Hariyono, K., \& Winarso, S. 2014. Penambahan Nutrisi Pada Tiga Varietas Melon Untuk Meningkatkan Hasil Dan Kualitas Buah. Agritro Jurnal Ilmu-Ilmu Pertanian, 147-158.

Direktorat Jenderal Hortikultura. 2015. Statistik Produksi Hortikultura Tahun 2014.

European and Mediterranean Plant Protection Organization. 2017. Salvinia molesta D.S. Mitch. EPPO Bulletin, 47(3), 531-536. https://doi.org/10.1111/epp.12428

Forneck, S., Fuad Hassan, M., Noulekoun, F., \& Ponzoni Frey, G. 2015. Coping with the Floods - Evaluation of Adaptation Technologies for Agriculture in Bangladesh. ZEF Doctoral Studies 
Program, Term Paper.

Haryono, Noor, M., Syahbuddin and Sarwani,

M. 2013. Lahan Rawa : Penelitian dan

Pengembangan. Badan Penelitian dan

Pengembangan. Kementerian Pertanian (in Indonesia)

Headley, T. R., \& Tanner, C. C. 2008. Floating

Treatment Wetlands: an Innovative Option for Stormwater Quality Applications. 11th International Conference on Wetland Systems for Water Pollution Control, 11011106.

Hussner, A., Stiers, I., Verhofstad, M. J. J. M., Bakker, E. S., Grutters, B. M. C., Haury, J., van Valkenburg, J. L. C. H., Brundu, G., Newman, J., Clayton, J. S., Anderson, L. W. J., \& Hofstra, D. 2017. Management and control methods of invasive alien freshwater aquatic plants: A review. Aquatic Botany, 136, 112-137. https://doi.org/10.1016/j.aquabot.2016.08.0 02

Ibironke, S. C., \& Oyeleke, O. W. 2014. Contributions of Melon Production to Livelihood Sustainability of Rural Farming Households in Oyo State , Nigeria . Agriculture and Healthcare, 4(12), 8-19.

Irfanullah, H. M., Adrika, A., Ghani, A., Khan, Z. A., \& Rashid, M. A. 2008. Introduction of floating gardening in the north-eastern wetlands of Bangladesh for nutritional security and sustainable livelihood. Renewable Agriculture and Food Systems, 23(2), 89-96. https://doi.org/10.1017/S174217050700207 4

Jung, C., \& Müller, A. E. 2009. Review : Flowering time control and applications in plant breeding. Trends in Plant Science, 14(10), 563-573. https://doi.org/10.1016/j.tplants.2009.07.00 5

Koutika, L., \& Rainey, H. 2015. A Review of The Invasive, Biological and Beneficial
Characteristics of Aquatic Species Eichornia crassipes and Salvinia Molesta. Applied Ecology and Environmental Research, 13(1), 85-97. https://doi.org/10.15666/aeer/1301

Makful, Hendri, \& Sahlan. 2013. Evaluation of Two Superior Variety Candidates of Melon in West Sumatra, West Java and East Java. American-Eurasian J.Agric \& Environ. Sci, 13(5), 690-695. https://doi.org/10.5829/idosi.aejaes.2013.13 .05 .1953

Marlina, N., \& Syafrullah. 2014. Pemanfaatan Jenis Kompos Rumput Rawa Pada Mentimun ( Cucumis sativus L .) dengan Teknologi Rakit Terapung Di Lahan Lebak Compost Utilization of Marsh Grass In Cucumber ( Cucumis sativus L .) using Floating Rafts Technology at Swamp Land. Prosiding Semnas LSO, September, 281288.

Mazuela, P., \& Urrestarazu, M. 2009. The Effect of Amendment of Vegetable Waste Compost Used as Substrate in Soilless Culture on Yield and Quality of Melon Crops. Compost Science and Utilization, 17(2), 103-107. https://doi.org/10.1080/1065657X.2009.107 02408

Monteiro, R. O. C., Coelho, R. D., \& Monteiro, P. F. C. 2014. Water and nutrient productivity in melon crop by fertigation under subsurface drip irrigation and mulching in contrasting soils. Ciencia Rural, 44(1), 25-30. https://doi.org/10.1590/S010384782013005000151

Mustaqim, R., Armaini, \& Yulia, A. E. 2016. Pengaruh Pembeian Kompos Tandan Kosong Kelapa Sawit dan Pupuk NPK Terhadap Pertumbuhan dan Produksi Tanaman Melon (Cucumis melo). JOM Faperta, 3(1), 1-13.

Neatrour, M. A. 2005. Factors affecting root 
system response to nutrient heterogeneity in forested wetland ecosystems By Factors affecting root system response to nutrient heterogeneity in forested wetland ecosystems (Issue April). Virginia Polytechnic Institute.

Pantanella, E., Cardarelli, M., Danieli, P. P., MacNiven, A., \& Colla, G. 2011. Integrated Aquaculture - Floating Agriculture: Is It a Valid Strategy to Raise Livelihood? Acta Horticulturae, 921, 79-86. https://doi.org/10.17660/ActaHortic.2011.9 21.9

Park, Y. H., \& Seo, B. S. 2012. Changes in Growth and Quality of Melon (Cucumis melo L.) and in Soil Nitrogen Forms due to Organic Fertilizer Application. Korean Journal of Soil Science and Fertilizer, 45(6), 1009-1016. https://doi.org/10.7745/kjssf.2012.45.6.100 9

Risyad, S., \& Ainun, N. 2015. Pengaruh Media Tanam dan Pupuk Hayati Agrobost Terhadap Pertumbuhan dan Hasil Tanaman Melon (Cucumis melo L.) Dalam Polybag. Agrosamudra, 2(2), 61-70.

Ritung, S., Nugroho, K., Mulyani, A., Suryani, E. 2011. Petunjuk Teknis Evaluasi Untuk Komoditas Pertanian (Edisi Revisi). Balai Besar Penelitian dan Pengembangan Sumberdaya Lahan Pertanian. Badan Penelitian dan Pengembangan Pertanian. Bogor

Sari, S., Rosmawaty, T., \& Gultom, H. 2012. Uji Penggunaan Ethrel dan Pupuk NPK Terhadap Produksi Melon (Cucumis melo L). Dinamika Pertanian, 27(3), 141-148.

Schuck. 2005. United States Patent: Floating Island Planting System.

Sharma, S. P., Leskovar, D. I., Crosby, K. M., \&
Volder, A. 2017. Root growth dynamics and fruit yield of melon (Cucumis melo L) genotypes at two locations with sandy loam and clay soils. Soil and Tillage Research, 168 , $50-62$. https://doi.org/10.1016/j.still.2016.12.006

Simanungkalit, P., Ginting, J., \& Simanungkalit, T. 2013. Respon Pertumbuhan Dan Produksi Tanaman Melon (Cucumis melo L.) Terhadap Pemberian Pupuk NPK Dan Pemangkasan Buah. 1(2), 238-248.

Surtinah. 2017. Evaluasi Deskriptif Umur Panen Melon (Cucumis melo L) Di Pekanbaru. Jurnal Ilmiah Pertanian, 14(1), 65-71. https://doi.org/10.1016/j.procs.2019.01.106 \%0Ahttps://doi.org/10.1016/j.apenergy.201 9.114422\%0Ahttp://dx.doi.org/10.1016/j.ijf atigue.2008.11.016\%0Ahttp://www.ansr.pt/ Estatisticas/RelatoriosDeSinistralidade/Pag es/default.aspx\%0Ahttp://dx.doi.org/10.101 $6 / j$.

Syafi'i, M. 2005. Pengaruh konsentrasi dan waktu pemberian gibberellin ( GA 3 ) terhadap pertumbuhan dan hasil tanaman melon ( Cucumis melo 1 .) dengan sistem tanam hidroponik irigasi tetes. Universitas Sebelas Maret.

Taha, M., Omara, K., \& Jack, A. El. 2003. Correlation among Growth, Yield and Quality Characters in Cucumis melo L . Cucurbit Genet. Coop. Rep., 26(1), 9-11.

Wisdom, B., Nyembezi, M., \& Agathar, K. 2017. Effect of different vermiculite and pine bark media substrates mixtures on physical properties and spiral rooting of radish (Raphanus sativus L.) in float tray system. Rhizosphere, 3, 67-74. https://doi.org/10.1016/j.rhisph.2017.01.00 2. 